\title{
＜研究と報告 >
}

\section{作業療法による視空間失認の改善}

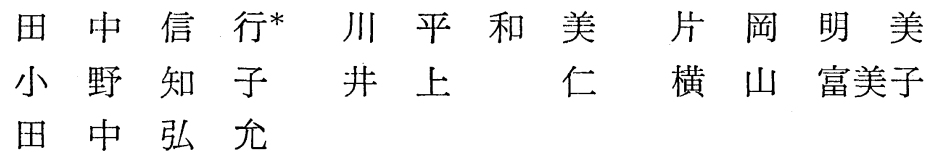

\begin{abstract}
著者 田中 信行 川平 和美 -片岡 明美 -小野 知子・井上借山富美子・田中 弘允

題名 作業療法による視空間失認の改善

要旨 視空間失認を有する脳卒中患者 24 名を, 運 動・ADL 訓練主体のコントロール群 (8 名) と空間認 知能を刺激する作業療法を行った OT 群 (16名) 飞 分け, 定量的視空間認知テストにより作業療法の効果 を評価した。両群は年㱓, 発症後経過, 傷害半球, 入 院時認知テスト得点, IQ, 運動機能, ADL に関して ほ结同レベルにあったが，退院時の認知テスト得点は コントロール群で不変, OT 群で有意に改善され, 作業 療法の学習転移的効果が推測された。運動機能, ADL の改善度は両群で差がなかったが, それは現在の ADL テストが主に運動機能のみを評価しているため と思われた。

キイワード：視空間失認, 作業療法
\end{abstract}

リ八医学 21: 437-441,

1984

\section{I.はじめに}

脳血管障害をはじめ種々の中枢神経障害でしばしば見 られる視空間認知障害 (視空間失認) visuospatial agnosia は, 半側空間の無視や不注意, 自己および自己と周囲空 間との立体的定位の障害や距離感の歪みのために，種々 の運動や作業能力, さらには情緒にも著しい障害を及ぼ す ${ }^{1 \sim 5)}$. その治療はりハビリ遂行上重要な課題であり， 従来成人では障害側への注意の集中や健常側での作業の 促進を行う機能的アプローチと，空間認知そのものに重 点を执いた訓練を汎化させる学習転移的アプローチが行 われてきだ,6,14 16)。しかしこれらの効果や優劣につい ては, 同レベルの障害者間での対照実験の困難さと, 視 空間失認自体の定量的評価の困難さのため明確な結論が 得られていない。

今回，共同執筆の横山ら ${ }^{7)}$ の考案した定量的視空間認 知テストを用いて, 脳卒中後の視空間失認患者を, 通常 の ADL, 運動訓練のみを行った群と, 視空間認知能を刺

1984年 6 月 27 日受理（至急揭載）

* 鹿児島大学医学部霧島分院
激すると思われる絵画の模写や欧り絵, ちぎり絵, あわ せ絵，ペグボードや積木を用いた課題構成等の作業療法 を積極的に行った群に分けて評価し, 視空間失認に対す る作業療法の効果を認めたので報告する.

\section{II. 対象と方法}

対象は, 当院入院時に横山らの定量的視空間認知テス 卜7)（以下失認テスト）で 89 点以下の脳卒中後遺症患者 24 名 (男 16 名, 女 8 名, $53.9 \pm 12.7$ 歳) である.

このうちコントロール群とした 8 名では患者自身が作 業療法よりも運動機能の回復に関心が強く, 通常の $\mathrm{ADL}$, 運動訓練を主体に行った. しかしこの群が特に種 種の訓練に拒否的あるいは不熱心ということはなく， たこの群でも障害側空間への注意や健常側での作業をす すめる，いわゆる機能的アプローチは常時行った，他の 16 名 (OT 群) では通常の ADL, 運動訓練に加兄て, 視空間認知能を刺激すると思われる種々の作業療法を朝 夕各 30 分程度行った。すなわち簡単な線画や文字の模 写，ペグボードや積木の移しかえやそれを用いた図型課 題の作成，あわせ絵や形あわせのパズル，下絵に小さな 紙片を貼りつけるちぎり絵やぬり絵, 網目をししゅう采 でかがって模様を作る手芸や鞇工を，各人の能力に合 わせて行った。

知能評価は長谷川式8 を用いた。運動機能の評価は上 田らの 12 段階法 ${ }^{9}$ と, 寝返りから自由歩行に至る下肢運 動能力を 70 点, 廃用手から実用手に至る上肢機能を 30 点, その合計を総合運動能力とする評価法 ${ }^{10}$ を用いた。 ADL は病室での移動, 食事, 排泄, 整容等に関する自 立度を 100 点満点で評価した ${ }^{11)}$.

コントロール群と OT 群の構成と入院時機能を表 1 に示した，両群の年齡，発症後経過期間には有意の差は ないが, コントロール群は女性患者が少なく, 今回の当 院入院期間は OT 群の約 2 倍と有意に長かった。障害 半球は両群ともほとんど右半球であった，原因疾患は， コントロール群では出血例が有意に多かったが, OT 群 
表 1 入院時に扎けるコントロール群と OT 群の 構成

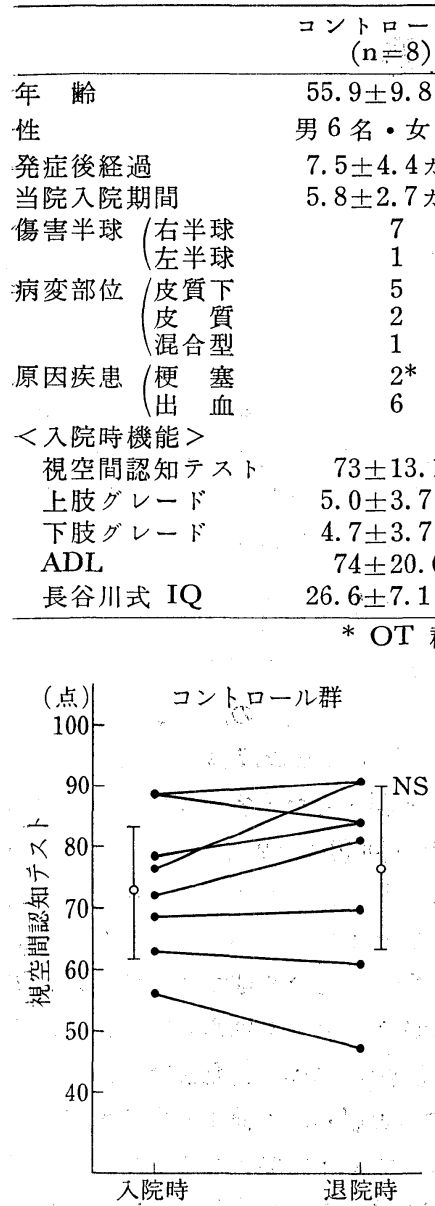

図1コントロール群, OT 群の視空間認知テストの変化 $(* * \mathrm{p}<0.01)$

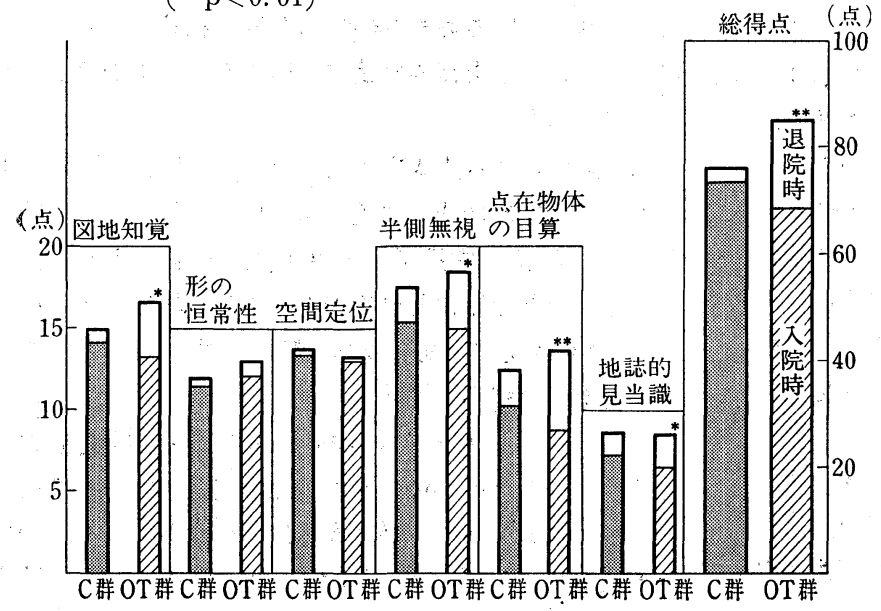

図 2 コントロール群 ( C 群), OT 群の視空間認知テスト各項目 の入院時之退院時の変化 $(* \mathrm{p}<0.05, * * \mathrm{p}<0.01)$
表 2. OT 群の病変部の違いによる視空間認知テス トの変化

\begin{tabular}{cccc}
\hline & 入院時 & 退院時 & 改善度 \\
\hline $\begin{array}{c}\text { 皮質下病変群 } \\
(\mathrm{n}=5)\end{array}$ & $70.2 \pm 16.3$ & $91.4 \pm 9.8$ & $21.9 \pm 8.4^{* *-}$ \\
$\begin{array}{c}\text { 質病変群 } \\
(\mathrm{n}=5)\end{array}$ & $74.1 \pm 13.2$ & $88.5 \pm 7.6$ & $14.2 \pm 9.1^{*} \dagger$ \\
$\begin{array}{c}\text { 混合病変群 } \\
(\mathrm{n}=6)\end{array}$ & $64.3 \pm 10.5$ & $74.1 \pm 7.7$ & $10.1 \pm 10.2^{*-}$ \\
\hline paired t-test による改善度の有意性 & $\begin{array}{r}* \mathrm{p}<0.05 \\
* * \mathrm{p}<0.01 \\
\end{array}$ & & $\begin{array}{l}\dagger<0.05 \\
\text { 分散分析による2 群間の有意性 }\end{array}$
\end{tabular}

では梗塞，出血が両者同数であった，病変部位はコント ロール群で皮質下病変例が，皮質病変例扣よび皮質，皮 質下の混合病変例より多かったが，OT 群では三者がほ ぼ同比率であった，入院時のコントロール群，OT 群の 認知テスト得点, 上下肢機能グレード, 運動機能得点,

ADL，長谷川式 IQ にはいずれも有意の差 はなく, 両群は機能的にほぼ同レベルにあ ると思われた。

\section{III. 結 果}

1) 視空間認知テスト得点の変化

入院時拉よび退院時に打けるコントロー ル群と OT 群の視空間認知テスト総得点 の変化を図 1 に示した。退院時のコントロ 一ル群の得点增加は平均 $2.5 \pm 2.4$ 点にすぎ なかった。一方 OT 群では, 退院時に得 点增加を示するのが 16 名中 14 名, 平均 $14.7 \pm 4.3$ 点の有意の改善が見られ，作業 療法の視空間失認への効果が示唆された.

表 2 は入院時 CT 所見から, OT 群を皮 質下病変群, 皮質病変群, 打上び皮質・皮 質下の混合病変群に分けた時の失認テス卜 総得点の変化を示す, 入院時から混合病変 群の得点が最も低く, その改善度も平均 $10.1 \pm 10.2$ 点と最も低かったが，それで もコントロール群の平均改善度 $2.5 \pm 2.4$ 点より有意仿かった。 ついで皮質病変 群, 皮質下病変群の順に改善度が上昇し, 皮質下病変群の平均改善度 $21.9 \pm 8.4$ 点は 混合病変群のそれに比べて有意に高かっ 苋。

年齢の゙違いによる認知得点の゙改善度を比 較するため, OT 群を 60 歳未満（11 名） と 60 歳以上（5 名）に分けて検討したが, 

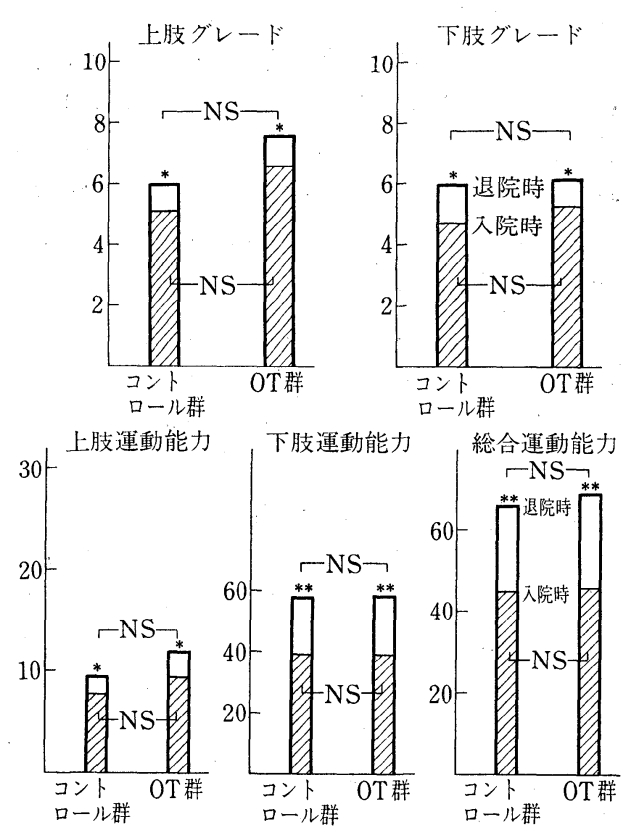

図 3 上田氏法による上・下肢運動機能グレ 一ドと筆者らの上・下肢運動能力評価の変化 $(* \mathrm{p}<0.05, * * \mathrm{p}<0.01)$

前者の平均改善度は $16.3 \pm 4.4$ 点, 後者は $13.6 \pm 3.9$ 点 といずれも有意の改善を示し，両者間に有意差はなかっ た. 発症後の経過期間の違いによる比較も, 発症後 6 カ 月以内 ( 9 例) の平均改善度は $14.9 \pm 4.5$ 点, 6 力月以 上（7 例）のそれは $12.4 \pm 3.9$ 点といずれも有意の改善 を示し，両者間に有意差は見られなかった。 また男性 （10名）と女性（6名）の比較でも，入院時抢よび退院 時得点, 改善度いずれについても両者間に有意差は見ら れなかった。

図 2 は失認テスト各項目の変化を示す、コントロール 群ではいずれの項目にも有意の改善は見られなかった が, OT 群では特に図地知覚, 半側無視, 点在物体のカ ウント，地誌的見当識で有意の改善が見られた．しかし 形の恒常性，空間定位についてはほとんぞ改善は見られ なかった。

2) 運動機能と ADL の変化

上田らの 12 段階評洒法による上下肢機能グレードの 変化を図 3 に示した。コントロール群，OT 群とひ退院 時には有意の改善が見られ，入院時，退院時グレード， あるいは改善度とも両群間に有意差は見られなかった。 また上肢運動機能を 30 点, 下肢運動機能を 70 点，その 合計を総合運動能力とする評価法でも,コントロール 群, OT 群とも退院時には有意の改善を示したが; 両群

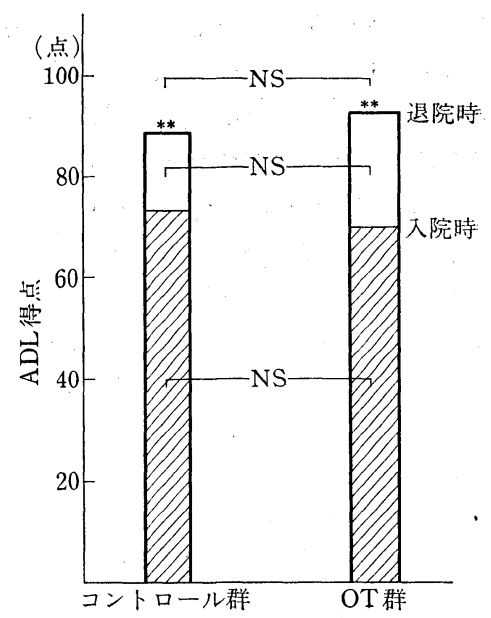

図 $4 \mathrm{ADL}$ 得点の変化 $\left({ }^{* *} \mathrm{p}<0.01\right)$

間には有意差はなかった。

$\mathrm{ADL}$ 得点の变化を図 4 に示したが，コントール群， OT 群とも退院時には有意の改善が見られた。 しかし入 院時, 退院時得点, 改善度とも両群間に有意差はなかっ た。また失認テストの改善度と ADL の改善度との間に も有意の相関は見られなかった。

\section{IV. 考 案}

視空間失認の治療に関して, Ayres ら ${ }^{12}$ は視聴覚, 触 覚, 深部覚の適切な刺激による視空間知覚の再統合を唱 えている，乙かしこの感覚統合的アプローチは，神経系 の発達, 統合に関する可塑性の少ない成人には適用が困 難で, ${ }^{33)}$ ，実際的動作の習熟や 健側視空間での生活の工. 夫，適応を図る，機能的アプローチが経験的に有効なも のとして行われてきだ.

一方，より積極的に視空間認知を刺激する訓練を実施 し，その機能の賦活，沉化を図る学習転移的アプローチ の有用性も報告されている。すなわち，Weinberg ら は右半球障害失認患者で, 視覚的走査, 追跡訓練により 視空間認知能の向上を認めて物り，またChedrú $ら^{15)}$, Diller $5^{16)}$ は重複視覚刺激 double simultaneous stimulation の弁別訓練, あるいは積木訓練がこれらの認知能を 高めることを報告している。しかしこれらも訓練に用い た要素的認知力の向上にすぎず，視空間認知能の沉化， 再編成は非常に困難であるとし，前述の経験的，機能的 アプローチの重要性を主張する意見も強い3).

この意見の違いの生ずる理由として，第 1 亿視空間失 認の回復も, 年龄, 原疾患, 障害半球, 病変部位, 治療 開始時期, その他の中权障害や合併症の存在が複雑に関 与し，比較すべき対照群の設定が困難なこと，第 2 亿従 
来の積木課題や描画を用いた失認テストは，視空間失認 患者でもしばしば見られる失行, 失語, 知能低下, 運動 麻痺の影響が大きく，またその定量的評価む困難である ことがあげられよう。

今回われわれは，視空間知覚を刺激すると思われる絵 画の模写や奴り絵, ちぎり絵やあわせ絵, 積木やペグボ 一ドを用いた課題練習, 手工芸等の作業療法により, 視 空間認知テスト得点の改善, すなわら学習転移的アプロ 一チの有効性を認めた。評価に用いた横山らの失認テス トが, Yes-No 式の簡単な応答により失行, 失語, 痴呆, 運動麻瘦の影響を可及的に少なくしうることは既報の通 りである7゙. 今回のコントロール群は作業療法よりる運 動訓練に関心を示した群であるが, 年齢, 治療開始時 期, 障害半球, 入院時の認知機能や運動機能, ADL, IQ に関しては, コントロール群，OT 群はほぼ同レベルに あった（表1）。コントロール群は OT 群に比して女性 が少ないが, Hier ら ${ }^{17)}$ は視空間失認の回復に男女差は ないとしている. Kaplan ら²)は, 同年齢, 同程度の傷害 では女性の認知能低下が軽いと報告しているが，今回は OT 群の男女間に入院時失認テスト得点赫よびその改善 度に関して有意差はなかった。

一般に発病後 6 力月位は認知能にも自然回復があると いわれるが ${ }^{17,18)}$ ，コントロール群, OT 群の治療開始時 期汇差はなく, OT 群の発病後 6 カ月以内扰よび以上群 とも同程度に有意の認知テスト得点の向上が見られた。 また発病後 1 年以上の 2 例でもそれぞれ 15 点, 18 点の 改善を示し, OT 群の失認テストの改善は単なる自然回 復とは考兄られない。テストへの馴れによる得点増加 も, 両群とも入院時と退院時のみの検査であり, OT 群 の作業療法にもテスト々類似の課題は含まれていないこ とから否定的である。病変部位の影響は一般に表 2 亿示 されたごとく，皮質下病変が最も回復しやすいといわれ る. コントロール群ではこの皮質下病变, しかも出血例 が最も多く, 今回の治療にも OT 群の約 2 倍の期間を かけたが，視空間認知力の改善は見られなかった.結局， OT 群がコントロール群に比して認知能力の回復に特に 有利な条件をそなえていたとは考学られず，OT 群の視 空間認知テスト得点が有意に高い改善度を示したこと は，視空間認知能を刺激する作業療法の効果と考兄られ る.

しかし認知テスト各項目別に見ると(図 2)，有意の改 善を示したのは図地知覚, 半側無視, 点在物体のカウン ト，地誌的見当識という，いずれも半側空間への認知機 能を基盤とする項目であり, 細かな形の恒常性や上下, 左右の空間的定位の弁別は有意の改善を示さなかった。
われわれの作業療法もよく見ると, 戝形模写, 積木やへ グの移動, 队り絵, ちぎり絵, 模様編及等の半側空間へ の注意を促進する課題が多く, 細かな形の恒常性や上 下, 左右の弁別を要する課題は少ない。すなわち訓練し た認知能力のみが向上したとも考兄られ，厳密な意味で の学習転移的アプローチの有効性の証明には, さらに今 後深い検討が必要であろら.

OT 群に抢ける視空間認知能力の改善にも拘らず，上 下肢機能グレードや運動能力, ADL の改善度はコント ロール群，OT 群注ぼ同程度であった（図 3，4）。視空 間失認がスムーズな着衣や移乘, 移動動作, 連続した動 作遂行の障害をきたすことは良く知られている。乙かし 通常の ADL テストは移動, 食事, 排泄, 整容が可能か 否かといら運動機能を主体に評価しており, 認知能を含 めた動作遂行の課程やスムーズさの評価がないため, OT 群の平均 14.7 点程度の 認知能の改善ではコントロール 群と ADL テスト上の差が出なかったものと思われる. 今後認知能力を含めた ADL 評価のために, 上述の日常 生活動作に必要な物品の選別, 配列, 動作遂行時間, エ ラー評価も含めた新しい ADL 評価体系も考慮しつつあ る.

最も有効な作業療法の種類やその組み合わせ, 実施回 数, 実生活上の有効性等, 検討すべき課題は多い. しか しコントロール群に見られたごとく, 通常の ADL や運 動機能訓練, あるいは障害側空間への注意の集中や健側 空間での作業の促進という機能的対応のみでは視空間認 知能力自体の向上は期待できず, 今後視空間失認に対す

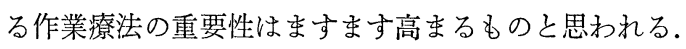

\section{文 献}

1) Lorenze EJ : Dysfunction in visual perception with hemiplegia : Its relation to activities of daily living. Arch Phys Med Rehab 43 : 514517, 1962.

2) Kaplan J, Hier DB : Visuospatial deficits after right hemisphere stroke. Am J Occup Ther $36: 315-321,1982$.

3）福井芳彦, 河内十郎 - 監訳, Siev E, Freishtat 著: 失行・失認の評価と治療一成人片麻瘦を中 心炡学書院, 東京, 1982 .

4) 横山富美子, 川平和美, 片岡明美・他：脳卒中 リハビリテーションに及活す視空間失認の影 響. リ八医学 $20: 153-157,1983$.

5）鎌倉矩子：失行症, 失認症の特性的把握と治療 的訓練. 総合リ> $3: 911-922,1975$.

6) Anderson EK, Choy E: Parietal lobe syndrome in hemiplegia ; A program for treatment. Am J Occup Ther 24:13-18, 1970

7) 横山富美子, 田中信行, 川平和美, 片岡明美 - 
他：視空間失認の定量的評価法.総合リ八 11 : 731-736, 1983.

8）長谷川和夫 : 痴呆の臨床評価. 臨床精神医学 $6: 351-357,1977$.

9）上田 敏, 福屋靖子, 間 得之, 長谷川恒雄 他 : 片麻瘴機能テストの標準化一12段階「片麻 痺回復グレード法」。総合リ八 $5: 749-766$, 1977.

10）川平和美, 田中信行, 横山富美子, 内田愛・ 他 : 脳卒中患者の心理. 総合り"、10:11071113, 1982.

11）パネル討論「ADL 訓練」, リ八医学 $18: 122-$ 146, 1981.

12) Ayres AJ : Interrelationship among perceptualmotor functions in children. Am J Occup Ther $20: 68-71,1966$.

13) Mack W, Lindquist JE, Parham JD : A synthesis of occupational behavior and sensory integration concepts in theory and practice. Part 1. Theoretical foundations, Part 2.
Clinical applications. Am J Occup Ther 36 : 365-374, 433-437 1982.

14) Weinberg J, Diller L, Gordon WA, Gerstman LJ, et al : Visual scanning training effect on reading-related tasks in acquired right brain damage. Arch Phys Med Rehab $58: 479$ 486, 1977.

15) Chedrú F, Leblanc $M$, Lhermitte F : Visual searching in normal and brain-damaged subjects. Cortex 9 : 94-111, 1973.

16) Diller L : Studies in cognition and rehabilitation in hemiplegia. Research Grant \#RD 2666-P, Institute of Rehabilitation Medicine, New York, N.Y., July, 1971.

17) Hier DB, Mondlock J, Kaplan LR : Recovery of behavioral abnormalities after right hemisphere stroke. Neurology 33 : 345-350, 1983.

18) Lowson IR : Visual-spatial neglect in lesions of the right hemisphere : A study in recovery. Neurology $12: 23-33,1962$.

\section{EFFECT OF OCCUPATIONAL THERAPY ON VISUOSPATIAL PERCEPTION IN POSTAPOPLECTIC PATIENTS \\ by}

Nobuyuki Tanaka, Kazumi Kawahira, Akemi Kataoka, Tomoko Ono, Jin Inoue, Fumiko Yokoyama and Hiromitsu Tanaka from

Kagoshima University Hospital Kirishima Branch

By means of a newly developed scale for visuospatial perception (VS score), we showed that the occupational therapy aimed at stimulating the visuospatial perception could improve VS score. Chronic postapoplectic patients $(6.9 \pm 4.4$ months after stroke) with decreased VS score $(71.5 \pm$ 13) were classified into two groups; Control group consisting of 8 patients ( $56 \pm 10$ yrs) who received ordinary rehabilitation program for hemiplegia and OT group consisting of 16 patients ( $53 \pm 13 \mathrm{yrs}$ ) who received occupational therapy such as block design, peg transfer, chopped figure arrangement, painting of line drawing and some manual works aimed at stimulating the visuospatial perception. Both groups were equally trained to be aware of visuospatial agnosia and to be habituated to the work at the preserved visual space. At the time of admission, the OT group and the Control group were roughly equivalent in terms of the age of the subjects, time after stroke, involved hemisperes, IQ's, motor and ADL scores, and VS scores, while in the Control group the number of males as well as incidence of subcortical lesions and of hemorrhage were greater and the therapy duration was longer as compared to the OT group.

At the time of discharge, OT group showed a significant increase in VS score $(+14.7 \pm 4.3)$ whereas Control group showed no improvement $(+2.5 \pm 2.4)$. Although the improvement of VS score in OT group was not affected by age, sex and duration after stroke, it was most remarkable in patients with subcortical lesions. Motor and ADL scores were significantly and similarly improved in both groups.

These results would suggest that the occupational therapy aimed at stimulating visuospatial perception is useful for improving visuospatial agnosia after stroke while the ordinary motor and ADL trainings do not improve visuospatial recognition. 